\title{
An empirical study to determine the critical success factors on customer retention: A case study of Iranian banking sector
}

\author{
Neda Jomehri $^{a}$, Hassan Javanshir ${ }^{a^{*}}$ and Sadollah Ebrahim Nezhad ${ }^{b}$
}

${ }^{a}$ Department of Industrial Engineering, Islamic Azad University, South Tehran Branch, Tehran, Iran ${ }^{b}$ Department of Industrial Engineering, Islamic Azad University, Karaj Branch, Karaj, Iran

\begin{tabular}{l}
\hline A R T I C L E I N F O \\
\hline Article history: \\
Received 30 August 2010 \\
Received in revised form \\
16 November 2010 \\
Accepted 18 November 2010 \\
Available online \\
19 November 2010 \\
\hline Keywords: \\
Customer value \\
Customer satisfaction \\
Customer loyalty \\
Customer retention \\
Banking industry
\end{tabular}

\section{Introduction}

Banking sector is one of the most competitive industries since banks not only compete with each other but also with other financial institutions (Kaynak \& Kucukemiroglu, 1992; Hull, 2002). Most banks have similar products and services and only better quality product with lower price could be a good measure to distinguish one bank from its competitors. Therefore, maintaining the market share plays an important role on achieving competitive advantages. Different studies have shown that customer retention is up to ten times cheaper than attracting new customers (Heskett et al., 1990). As a result, one may suggest to spend more of a business resources on keeping the existing customers rather than trying to attract new ones. The expenditures of acquiring customers to replace those who * Corresponding author. Tel: +98-912-501-1941

E-mail addresses: seda2090@yahoo.com (N. Jomehri) 
have been lost are high. This is because the cost of acquiring customers occurs only in the beginning stages of the commercial relationship (Reichheld \& Kenny, 1990).

The long term customers can be considered as the best candidate to advertise about the firm as long as they are satisfied with the delivered products and services. Also These customers usually are less sensitive to prices. There are also some evidences to confirm that a five percent reduction on the customer defection could double the profitability (Healy, 1999).

There are different key factors affecting customer intentions to continue his/her relationship with a bank such as the range of services, rates, fees and prices charged (Abratt \& Russell, 1999). Since the products and services provided by most banks are often similar, under such circumstances, customer retention, as a defensive strategy, is one of the best ways to survive in the current competitive market.

The purpose of this paper is to empirically investigate the relationships between customer value, customer satisfaction, customer loyalty and customer retention in banking sector. The components of customer value are: functional value, social value, emotional value and customer perceived sacrifices. This study is expected to contribute to a better understanding of the effects of different aspects of customer value on the customer satisfaction, customer loyalty and customer retention.

This paper is organized as follows. section 2 explains the concept of customer value and its key aspects and the effects that it has on customer satisfaction, customer loyalty and customer retention. Section 3 studies the details of our survey and statistical analysis and the concluding remarks are given in section 4 to summarize the contribution of the paper.

\section{Theoretical background and conceptual framework}

\subsection{Customer value}

The concept of customer value is one of the most important factors in the successes of an organization and it can be considered as an important source of competitive advantage for any organization (Woodruff, 1997). Customer value is known as the main basis for any marketing activity and has been recognized as an important strategic tool to attract and retain customers (Wang et al., 2004).

In recent years, the importance of customer value has been widely considered, but there is still no comprehensive definition available. Customer value is the customer's overall assessment of the utility of a product based on the perception of what is gained in an exchange for what is given (Zeithaml, 1998). Customer value is a triangular model which includes product quality, service quality and product or service price and consumers consider these three factors to assess the real value (Naumann, 1995).

Butz and Goodstein (1996) defined the value as an emotional commitment created between customer and supplier after customer has used the supplier's products or services for a while. Woodruff (1997) defined the value as customer preferences and assessment of a product considering how much it can satisfy his/her goals and objectives.

Kotler (1999) specified that customer value is the overall assessment on how much the customer's needs when the product is purchased, has been satisfied. Another definition of the value is the combination of customer attitude and experiences as a result of using the purchased product. As we can observe, there are many cases where we see the value is defined as what is received and what is paid. Thus, In this study, we adopt the definition of value as a balance between what a customer pays and what he/she gains. 


\subsection{Key aspects of customer value}

For a long time customer value has been considered as a trade off between quality and price but the later studies indicate that there are other factors affecting the customer value. Sweeney and Soutar (2001) stated that if an organization wants to determine its customer value, it should review the reasons that cause customers to stay with or abandon the organization. According to Sheth et al. (1991) customer value is composed of five elements which are functional, social, emotional, epistemic and conditional values. However, all these elements are not always apparent. Sweeney and Soutar (2001) developed PERVAL (perceived value) model. In this model, they divided functional aspect of customer value into quality and price. They also believed that we do not have to consider epistemic value and conditional value whenever we deal with durable goods. While quality is one of the most significant gains from customer's perspective, what he or she gives, is not limited to the charged prices. Heskett et al. (1994) and Zeithaml (1998) all emphasized that we must consider time, energy and effort in addition to price.

Key dimensions of customer value is defined as following:

- Functional value: It refers to real or expected effects customers will receive from purchased products or services.

- Emotional value: It is the reaction towards purchased products or services.

- Social value: It refers to the social utility derived from the purchased products or services.

- Customer perceived sacrifices: It refers to monetary and non-monetary costs a customer must give up in order to acquire a product or service.

\subsection{Customer satisfaction}

Customer satisfaction has been one of the most common measurement metric of customer perceived concepts used by businesses (Gupta \& Zeithaml, 2007) because it is considered as a generic metric and can be used for different industries. Although there is not a precise definition for this construct, it is easily understood by mangers and customers. According to Kotler (1997) customer satisfaction is defined as the difference between the level of perceived performance and customer's expectations. Thus, customer satisfaction is not only the outcome of the perceived performance of the product, but also it reflects customer's expectations and a comparison between these two elements will determine customer satisfaction. In other words, when the customer expectations do not match with his/her perceptions, customer dissatisfaction appears. Fornell (1992) performed an empirical study on Swedish customers and revealed that although customer satisfaction and quality play important roles for most organizations but there are industries such as banks, insurance, mail order and automobiles where customer satisfaction is more important since it creates more loyalty.

Ioanna (2002) reported that product differentiation in a competitive environment like the banking industry is almost impossible since banks often offer similar services. For instance, there is usually little difference in the prices charged for similar financial products. Thus, banks try to differentiate themselves from their competitors mostly by improving the quality of delivered services. In the banking sector service quality is one of most fundamental factors impacting satisfaction level. However, Reidenbach (1995) stated that customer value is a more viable factor than customer satisfaction since it considers the cost of products in addition to other important factors. Customer value is a dynamic construct and must be controlled whereas customer satisfaction is customer's response to the values obtained from purchased products. Therefore, banks or insurance companies must understand how customers define the value so that they could create value added services.

There are some evidences that indicate there is a positive relationship between the customer value and satisfaction (Anderson \& Mittal, 2000, Yang \& Peterson, 2004). Therefore we may propose the following four hypotheses presented in Table 1. 


\section{Table 1}

The necessary hypotheses concerning customer satisfaction and aspects of customer value

\begin{tabular}{ll}
\hline Item & Hypothesis \\
\hline H1 & $\begin{array}{l}\text { There is a positive relationship between customer value and customer satisfaction. } \\
\text { There is a direct and positive relationship between functional value and customer } \\
\text { satisfaction. }\end{array}$ \\
H1-2 & $\begin{array}{l}\text { There is a direct and positive relationship between social value and customer } \\
\text { satisfaction. }\end{array}$ \\
H1-3 & $\begin{array}{l}\text { There is a direct and positive relationship between emotional value and customer } \\
\text { satisfaction. } \\
\text { H1-4 }\end{array}$ \\
& $\begin{array}{l}\text { There is a direct and positive relationship between customer perceived sacrifices and } \\
\text { customer satisfaction. }\end{array}$
\end{tabular}

According to Reichheld and Sasser (1990), an increase on customer satisfaction could increase customer loyalty. Lovelock (1996) indicated that customer satisfaction is resulted when customers compare their expectations on a product with actual experiences of using that product and customer satisfaction is driven by customer loyalty, so we could expect a positive relationship between customer loyalty and customer satisfaction. Table 2 shows the hypothesis concerning this relationship.

\section{Table 2}

The hypothesis concerning the relationship between customer satisfaction and customer loyalty

Item Hypothesis

$\mathrm{H} 2$ There is a positive relationship between customer satisfaction and customer loyalty.

\subsection{Customer loyalty}

Attracting new customers is an expensive process and it actually turns profitable in later stages of customer's relationship with the firm. This relationship could be less costly only when a customer becomes loyal to the firm. There are different approaches to loyalty and one of them is called stochastic approach. In this approach, loyalty is a behavior and whenever a person buys a particular brand regularly, he/she is considered to be loyal to that brand (Kuehn, 1992). This approach cannot differentiate between spurious loyalty and true loyalty. The other approach considers loyalty as an attitude. According to Assael (1992) loyalty is customer's favorable attitude towards a brand which results in occurrence of repurchasing behavior. According to Zeithaml et al. (1996) loyal customers are interested in having good relationship with the organization and they normally behave differently. Loyal customers have more emphasis on social and emotional values and studies have revealed that creating and delivering superior customer value could contribute to an organization's efforts in building strong emotional relationships with its customers (Butz \& Goodstein, 1996). Thus, loyalty in such customers can be improved by providing superiority in specific aspects of customer value. Thus, we may propose the following four hypotheses presented in Table 3.

\section{Table 3}

The necessary hypotheses concerning the relationship between customer loyalty and aspects of customer value

\begin{tabular}{ll}
\hline Item & Hypothesis \\
\hline H3-1 & There is a direct and positive relationship between functional value and customer loyalty. \\
H3-2 & There is a direct and positive relationship between social value and customer loyalty. \\
H3-2 & $\begin{array}{l}\text { There is a direct and positive relationship between emotiomal value and customer loyalty. } \\
\text { H3-4 }\end{array}$ \\
$\begin{array}{l}\text { There is a direct and positive relationship between customer perceived sacrifices and } \\
\text { customer loyalty. }\end{array}$
\end{tabular}




\subsection{Customer retention}

A simple definition of customer retention is the customer's intention to keep using company's offerings. For instance a bank's customer is considered to be retained as long as he/she keeps his/her account open and active with the bank. Most of the studies which investigate the relationship between the customer satisfaction and actual customer behavior concentrate on the relationship between the customer satisfaction and customer retention (Reichheld \& Kenny, 1990; Reichheld \& Sasser, 1990; Reichheld et al., 2000). According to Mazumdar (1993) customers are becoming more value oriented than quality or price oriented. There are empirical evidences that customer value has significant influence on customer repurchase intentions and his or her intention to stay with a particular provider. Therefore, we may propose the following four hypotheses presented in Table 4.

\section{Table 4}

The necessary hypotheses concerning the relationship between customer retention and aspects of customer value

\begin{tabular}{ll}
\hline Item & Hypothesis \\
\hline H4-1 & There is a direct and positive relationship between functional value and customer retention. \\
H4-2 & There is a direct and positive relationship between social value and customer retention. \\
H4-3 & $\begin{array}{l}\text { There is a direct and positive relationship between emotional value and customer retention. } \\
\text { H4-4 }\end{array}$ \\
$\begin{array}{l}\text { There is a direct and positive relationship between customer perceived sacrifices and } \\
\text { customer retention. }\end{array}$
\end{tabular}

Since customer satisfaction could be the result of the performance of a service or product we may expect customer retention as long as the service or product is provided properly. Therefore, Table 5 summarizes the necessary questions.

\section{Table 5}

The necessary hypotheses concerning the relationships between customer retention and customer satisfaction and customer loyalty

\begin{tabular}{ll}
\hline Item & Hypothesis \\
\hline H5 & Customer satisfaction has a positive relationship with customer retention. \\
H6 & Customer loyalty has a positive relationship with customer retention. \\
\hline
\end{tabular}

Fig. 1 shows the relationship among different constructs originally introduced by Wang et al. (2004).

Customer Value

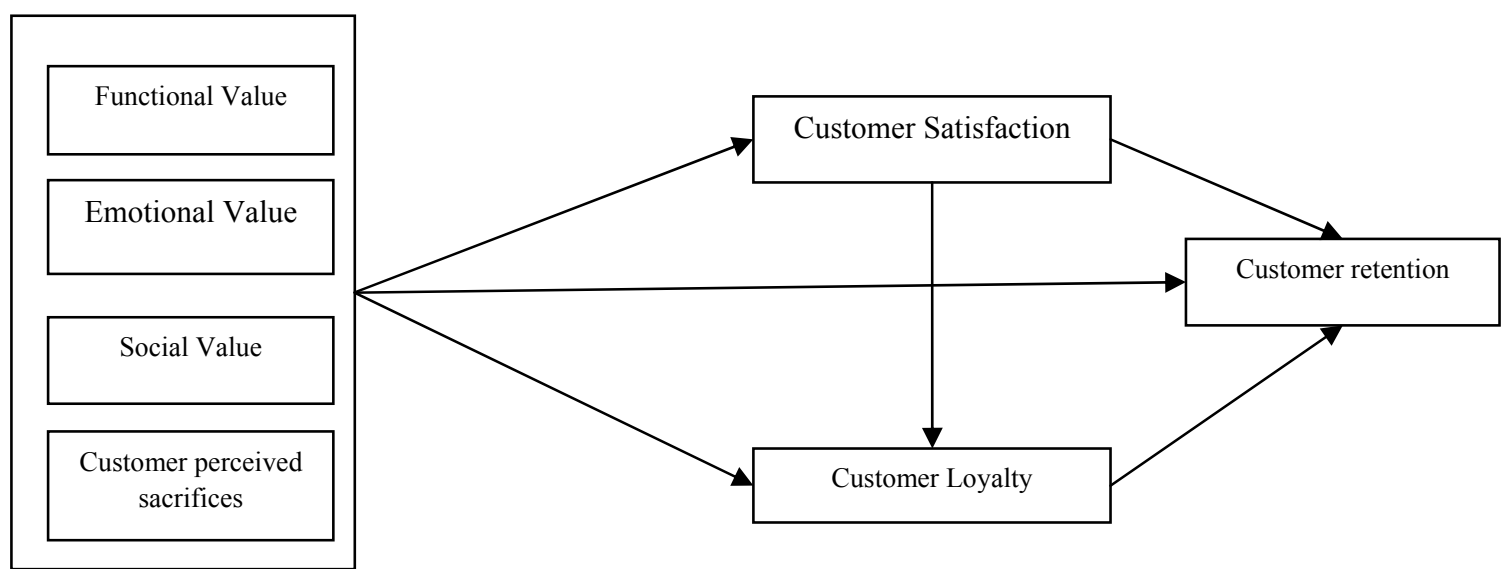

Fig. 1. The proposed framework 


\section{Methodology}

The proposed model of this paper is implemented on one of Iranian banks branches located in Tehran which is the capital city of Iran. The sample size is calculated as follows,

$$
N=Z_{\alpha / 2}^{2} \frac{p \times q}{e^{2}}
$$

where $N$ is the sample size, $p=1-q$ represents the probability, $z_{\alpha / 2}$ is CDF of normal distribution and finally $\varepsilon$ is the error term. For our study we assume $p=0.5, z_{\alpha / 2}=1.96$ and $e=0.99$, the number of sample size is calculated as $N=98$. We have distributed 125 questionnaire and received 106 ones. We have adopted the scale developed by Wang et al. (2004) to measure customer value dimensions. We have considered four items for functional value, five items for emotional value, three items for social value and finally six items for perceived sacrifices and the Cronbach alpha (Cronbach, 1951) were calculated as $0.856,0.935,0.865$ and 0.893 , respectively. In order to measure the customer satisfaction we have used four items provided by Wang and Lo (2003) and the Cronbach alpha was calculated as 0.932 . Customer loyalty was measured based on three items collected from Wang et al. (2004) and the Cronbach alpha was calculated as 0.897 . For customer retention, we have chosen two items from Wang et al. (2004) and Dimitriadis (2010) and the Cronbach alpha was calculated as 0.806. All items were measured using five-point Likert-type scales and the descriptors ranged from "strongly disagree", to " disagree", "neutral", " agree", and "strongly agree". According to Nunnally (1978), reliability occurs when Cronbach's alpha is above 0.7 . A value of $0.7-0.8$ is good but a value above 0.8 is very good. As we can observe, all calculated Cronbach alphas confirm the reliability of all the constructs of study. In order to conduct the data analysis we use partial least square method (Chin, 1998). One of estimation techniques for structural equation modeling (SEM) is PLS. An structural model has at least two dependent variables whereas one dependent variable plays as an independent variable for the other dependent variable.

The PLS is used once the sample size is small, the variables are not normally distributed, the number of independent variables is more than the number of observations, there is strong correlation among independent variables and the whole model is not stated, precisely (Bellman, 2003). To estimate the significance of the path coefficient, Bollen and Stine (1992) suggested the Boot-Strap method. Therefore, BootStrap method was applied to test the significance of the model's path coefficient. we used Visual PLS 1.04 software to analyze measurement model and structural model and the statistical package for social science version 16.0 (SPSS) to analyze the demographic data. Table 6 and Table 7 show different demographic characteristics of the respondents.

Table 6

Personal charachteristics of the respondents

\begin{tabular}{ccccccccccccccc}
\hline \multicolumn{1}{c}{ Sex } & \multicolumn{1}{c}{ Martial Status } & \multicolumn{4}{c}{$\begin{array}{c}\text { Education } \\
\text { Background(Years) }\end{array}$} \\
\hline Man & Woman & Single & Married & $<12$ & 12 & 14 & 16 & $>18$ & $<20$ & $21-30$ & $31-40$ & $41-50$ & $51-60$ & $>61$ \\
\hline 57 & 49 & 67 & 39 & 13 & 27 & 19 & 29 & 18 & 3 & 46 & 33 & 13 & 6 & 5 \\
\hline 53.8 & 46.2 & 63.2 & 36.8 & 12 & 26 & 18 & 27 & 17 & 2.8 & 43.4 & 31.1 & 12.3 & 5.7 & 4.7 \\
\hline
\end{tabular}

As we can observe from Table 6, our sample size incorporates more men than woman and there are more single than married. About 82 percent of the population of this sample size have university background and finally most of the people are older than 20 years. 
Table 7

The characterization of the respondents in terms of job title, income, etc

\begin{tabular}{llll}
\hline Variable & Attribute & Frequency & Percentage \\
\hline Job title & Employee & 25 & 23.8 \\
& Homemaker & 20 & 18.9 \\
& Retire & 11 & 10.4 \\
& Student & 13 & 12.3 \\
& Bussinessman & 37 & 34.9 \\
\hline Income(Thousand Rials) & $<300$ & 11 & 10.4 \\
& Between 301 and 500 & 28 & 26.8 \\
& Between 701 and 700 & 21 & 19.8 \\
& Between 701 and 900 & 21 & 19.8 \\
& More than 900 & 19 & 18 \\
\hline The average time to be the customer of & $<$ 12 month & 18 & 17 \\
bank(month) & Between 12 and 24 & 12 & 11.3 \\
& Between 24 and 36 & 26 & 24.5 \\
& Between 36 and 48 & 6 & 5.7 \\
& More than 48 & 44 & 41.5 \\
\hline
\end{tabular}

Table 8 summarizes the composite reliability and average variance extracted (AVE) for all constructs,

\section{Table 8}

The summary of the Composite reliability and AVE

\begin{tabular}{lcc}
\hline Variable & Composite reliability & AVE \\
\hline Perceived sacrifices & 0.91 & 0.62 \\
Functional value & 0.89 & 0.66 \\
Emotional value & 0.96 & 0.85 \\
Social value & 0.96 & 0.90 \\
Loyalty value & 0.93 & 0.82 \\
Maintaing customer & 0.91 & 0.84 \\
\hline
\end{tabular}

As we can observe, the composite reliability measured for all the constructs is greater than 0.89 which exceeds the suggested value of 0.7 (Hair et al., 1998). It means that all the constructs have high internal consistency and reliability.

The AVE value differs from 0.62 to 0.90 . These are also relatively high numbers which indicate that the model has good convergence validity (Fornell \& Larcker, 1981). All of the individual items are statistically significant and all factor loadings are higher than 0.7 (Chin,1998), thus the reliability of individual items is confirmed. Table 9 demonstrates these results .

According to Fornell and Larcker(1981) in order to examine discriminant validity, a construct's square of AVE must be greater than its correlation coefficients with other constructs. Thus, the constructs in our model have sufficient discriminant validity. 


\section{Table 9}

Loading and t-value

\begin{tabular}{|c|c|c|c|}
\hline construct & index & Loading & t-value \\
\hline \multirow[t]{6}{*}{ Perceived sacrifices } & SAC1 & 0.7359 & 16.7312 \\
\hline & $\mathrm{SAC} 2$ & 0.8226 & 26.656 \\
\hline & SAC3 & 0.7577 & 17.8302 \\
\hline & SAC4 & 0.7672 & 16.8951 \\
\hline & SAC5 & 0.7656 & 15.2263 \\
\hline & SAC6 & 0.8628 & 29.1162 \\
\hline \multirow[t]{4}{*}{ Functional value } & FUN1 & 0.8373 & 28.7084 \\
\hline & FUN2 & 0.8342 & 27.1083 \\
\hline & FUN3 & 0.8355 & 27.5161 \\
\hline & FUN4 & 0.7463 & 13.1617 \\
\hline \multirow[t]{4}{*}{ Emotional value } & EMO1 & 0.90 & 42.2718 \\
\hline & EMO2 & 0.9334 & 63.6393 \\
\hline & EMO3 & 0.9309 & 59.1676 \\
\hline & EMO4 & 0.9288 & 66.9586 \\
\hline \multirow[t]{3}{*}{ Social value } & SOC1 & 0.937 & 52.329 \\
\hline & $\mathrm{SOC} 2$ & 0.9685 & 122.7434 \\
\hline & SOC3 & 0.9431 & 67.4478 \\
\hline \multirow[t]{4}{*}{ Customer satisfaction } & SAT1 & 0.8898 & 41.8758 \\
\hline & SAT2 & 0.9051 & 42.2369 \\
\hline & SAT3 & 0.8704 & 22.5175 \\
\hline & SAT4 & 0.9154 & 59.7552 \\
\hline \multirow[t]{3}{*}{ Customer loyalty } & LOY1 & 0.8971 & 40.4321 \\
\hline & LOY2 & 0.9325 & 64.4025 \\
\hline & LOY3 & 0.8822 & 32.8461 \\
\hline \multirow[t]{2}{*}{ customer retention } & RET1 & 0.9242 & 59.6438 \\
\hline & RET2 & 0.9083 & 48.0761 \\
\hline
\end{tabular}

Table 10 shows the discriminant validity results for all constructs.

Table 10

The results for differential validity

\begin{tabular}{llllllll}
\hline & $\begin{array}{l}\text { Perceived } \\
\text { sacrifices }\end{array}$ & $\begin{array}{l}\text { Funtional } \\
\text { value }\end{array}$ & $\begin{array}{l}\text { Emotional } \\
\text { value }\end{array}$ & $\begin{array}{l}\text { Social } \\
\text { value }\end{array}$ & $\begin{array}{l}\text { Customer } \\
\text { satisfaction }\end{array}$ & $\begin{array}{l}\text { Customer } \\
\text { loyalty }\end{array}$ & $\begin{array}{l}\text { Customer } \\
\text { retention }\end{array}$ \\
\hline $\begin{array}{l}\text { Perceived } \\
\text { sacrifices }\end{array}$ & 0.79 & & & & & & \\
\hline $\begin{array}{l}\text { Funtional value } \\
\text { Emotional }\end{array}$ & 0.76 & 0.82 & & & & & \\
$\begin{array}{l}\text { value } \\
\text { Social value }\end{array}$ & 0.58 & 0.67 & 0.92 & & & & \\
$\begin{array}{l}\text { Customer } \\
\text { satisfaction }\end{array}$ & 0.72 & 0.67 & 0.74 & 0.95 & & & \\
$\begin{array}{l}\text { Customer } \\
\text { loyalty }\end{array}$ & 0.62 & 0.73 & 0.77 & 0.61 & 0.74 & 0.90 & \\
$\begin{array}{l}\text { Customer } \\
\text { retention }\end{array}$ & 0.66 & 0.76 & 0.78 & 0.64 & 0.75 & 0.80 & 0.83 \\
\hline \begin{tabular}{l} 
Note: Diagonal elements are square roots of the average variance extracted (AVE). \\
\hline
\end{tabular}
\end{tabular}

The results indicate that functional value has a direct and positive relationship with customer satisfaction $(p<0.01, \beta=0.43)$. Social value has a direct and positive relationship with customer 
satisfaction ( $p<0.05, \beta=0.13$ ), emotional value has a direct and positive relationship with customer satisfaction $(p<0.01, \beta=0.32)$ and customer loyalty $(p<0.01, \beta=0.40)$. Customer perceived sacrifices has a direct and positive relationship with customer satisfaction $(p<0.01, \beta=0.25)$. Customer loyalty is predicted by customer satisfaction with $(p<0.01, \beta=0.35)$. Finally, customer retention is predicted by customer satisfaction with $(p<0.01, \beta=1.67)$ and customer loyalty with( $p<0.01, \beta=0.39)$. Table 11 summarizes the results of analysis for the proposed model.

\section{Table 11}

Results of hypothesis tests

\begin{tabular}{llcll}
\hline Hypothesis & Path & $\beta$ & t-value & Result \\
\hline H1-1 & Functional value $\rightarrow$ Customer satisfaction & 0.43 & 4.84 & Confirm \\
H1-2 & Social value $\rightarrow$ Customer satisfaction & 0.13 & 1.78 & Confirm \\
H1-3 & Emotional value $\rightarrow$ Customer satisfaction & 0.32 & 3.28 & Confirm \\
H1-4 & Perceived sacrifices $\rightarrow$ Customer satisfaction & 0.25 & 3.31 & Confirm \\
H2 & Customer satisfaction $\rightarrow$ Customer loyalty & 0.35 & 3.92 & Confirm \\
H3-1 & Functional value $\rightarrow$ Customer loyalty & 0.09 & 1.11 & Reject \\
H3-2 & Social value $\rightarrow$ Customer loyalty & 0.08 & 1.21 & Reject \\
H3-3 & Emotional value $\rightarrow$ Customer loyalty & 0.40 & 3.72 & Confirm \\
H3-3 & Perceived sacrifices $\rightarrow$ Customer loyalty & -.02 & -.36 & Reject \\
H4-1 & Functional value $\rightarrow$ customer retention & 0.12 & 1.55 & Reject \\
H4-2 & Social value $\rightarrow$ customer retention & 0.10 & 1.48 & Reject \\
H4-3 & Emotional value $\rightarrow$ customer retention & 0.15 & 1.41 & Reject \\
H4-4 & Perceived sacrifices $\rightarrow$ customer retention & 0.05 & 0.67 & Reject \\
H5 & Customer satisfaction $\rightarrow$ customer retention & 1.67 & 1.74 & Confirm \\
H6 & Customer loyalty $\rightarrow$ customer retention & 0.39 & 3.27 & Confirm \\
\hline
\end{tabular}

The results indicate that customer value dimensions could explain 70 percent of the variance in customer satisfaction. In addition, customer value dimensions and customer satisfaction could explain 67 percent of the variance in customer loyalty. Customer value dimensions, customer satisfaction and customer loyalty could explain 70 percent of the variance in customer retention. As we can observe, the model could easily analyze the results. These values indicate that the structural equation model has strong predictive power. Fig. 2 demonstrates the significant paths of our purposed model .

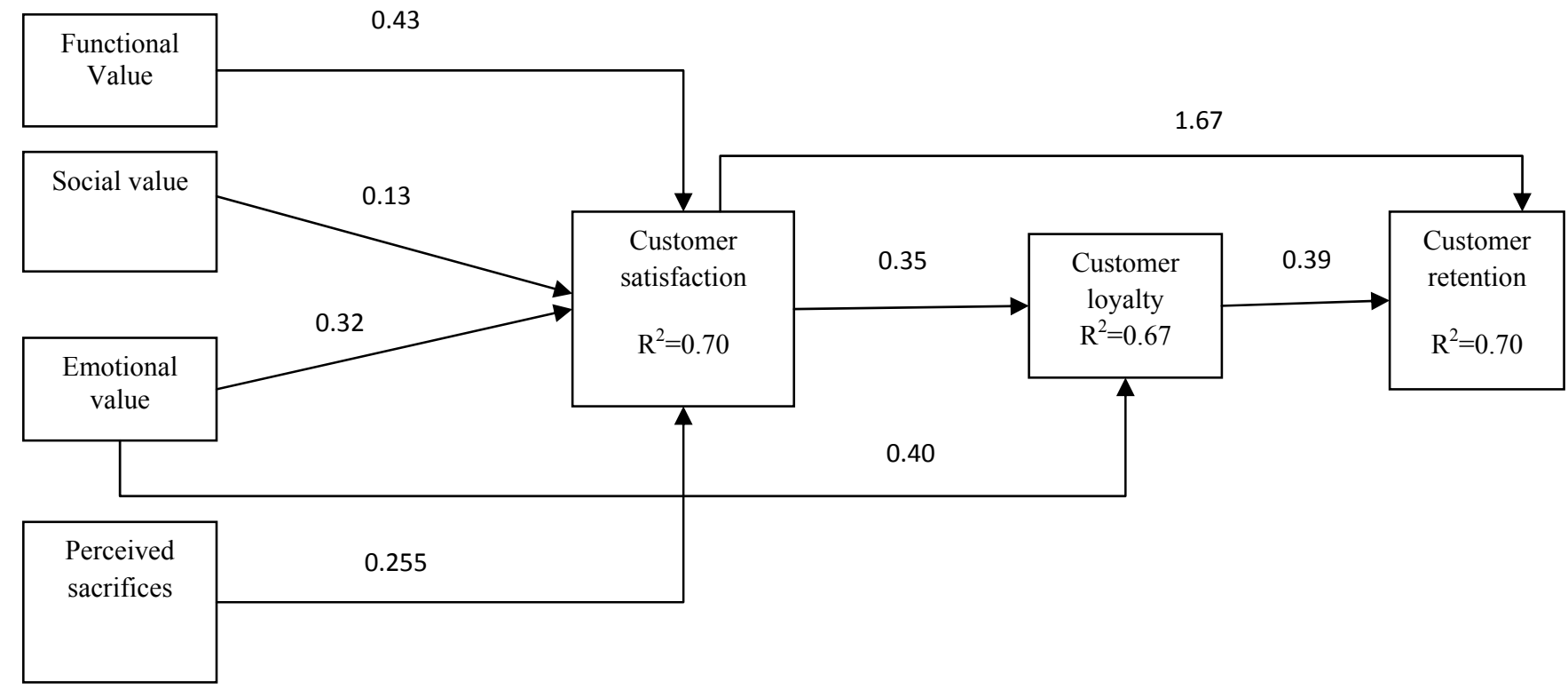


Fig. 2. The results of the proposed model

Since all aspects of customer value have direct and positive relationships with customer satisfaction we could also accept the first hypothesis (H1). Only emotional value has a direct and positive relationship with customer loyalty. Functional and social values as well as perceived sacrifices have indirect relationship with customer loyalty despite the customer satisfaction. Also, the results indicate that no aspects of customer value have direct and positive relationships with customer retention. However, customer satisfaction and loyalty definitely have positive impact on customer retention. Therefore, each aspect of customer value can positively influence customer retention through customer satisfaction and customer loyalty. Therefore managers in the banking sector must consider all these aspects in order to retain their existing customers.

In summary, we could conclude that customer retention is determined by customer satisfaction and customer loyalty with $\beta=1.67$ and $\beta=0.39$, respectively. However, since customer satisfaction not only has a direct and positive effect on customer retention, it also indirectly effects customer retention through customer loyalty, so we have $\beta=0.35 \times 0.39=0.14$. Therefore, the total effect of customer satisfaction on customer retention is $\beta=0.14+1.67=1.81$. we can conclude that customer satisfaction has more impact on customer retention.

\section{Conclusion}

In this paper, we have studied the effects of customer value and its key aspects on customer satisfaction, customer loyalty and customer retention in banking industry. The results indicate that all aspects of customer value have direct and positive impact on customer satisfaction. Therefore we could conclude that banks need to provide diversified products and services for their customer and elevate their social image in order to increase the level of customer satisfaction. The banks must also increase customer emotional value by providing easily accessible facilities such as automated teller machines, reliable internet facilities, etc. In this research we have found that emotional value is the only aspect of customer value that has a direct and positive relationship with customer loyalty. It is expected that customers who have pleasant experiences while using a bank's services and products will be more loyal to it in long term. We did not find any meaningful relationship between customer loyalty and functional value.

Functional value are mostly influential when there is a big difference between the levels of services of various banks. In our opinion, there is not a big difference on the level of services for different banks in Iran and we cannot use functional value to increase customer value. On the other hand, our respondents do not believe that this particular bank increase their social position so social value was unable to influence loyalty, significantly.

There were two limitations on this research. This study is a cross-sectional study and the construct investigations of the study are dynamic variables. The second one is that we empirically investigated our model in a specific sector which is the banking industry. Therefore, we suggest using other industries and economic sectors to verify the results.

\section{Acknowledgment}

The authors would like to thank the anonymous referees for their construction comments on an earlier version of this work. 


\section{References}

Abratt, R \& Russell, J. (1999). Relationship marketing in private banking South Africa. The International Journal of Bank Marketing, 17(1), 15-19.

Anderson, E. W., \& Mittal, V. (2000). Strengthening the satisfaction-profit chain. Journal of Service Research, 3(2), 107-120.

Assael, H. (1992). Consumer Behavior and Marketing Action, $4^{\text {th }}$ ed., PWS-KENT Publishing Company, Boston, MA.

Bellman, S. (2003). How to Use PLS. Working Paper, Graduate School of Management, University of Western Australia

Bollen K. A., \& Stine R. (1992). Bootstrapping goodness of fit measures in structural equation models. Sociological Methods and Research, 21(2), 205-229.

Butz, H. E. J. \& Goodstein, L. D. (1996). Measuring customer value: gaining the strategic advantage. Organizational Dynamics, 24(3), 63-77.

Chin, W.W. (1998).The partial least squares approach for structural equation modelling, in Marcoulides, G.A. (Ed.), Modern Methods for Business Research, Lawrence Erlbaum Associates, Mahwah, NJ, 295-336.

Cronbach, L. J. (1951). Coefficient alpha and the internal structure of tests. Psychometrika, 16(3), 297-334.

Dimitriadis, S. (2010). Testing perceived relational benefits as satisfaction and behavioral outcomes drivers. International Journal of Bank Marketing, 28(4), 297-313.

Fornell, C. (1992). A National Customer Satisfaction Barometer: The Swedish Experience. Journal of Marketing, 56(1), 6-21.

Fornell, C., \& Larcker, D. F. (1981). Evaluating Structural Equation Models with Unobservable Variables and Measurement Error. Journal of Marketing Research, 18, 39-50.

Gupta, S. \& Zeithaml, V. A. (2007). Customer metrics and their impact on financial performance, Marketing Science, 25(6), 728-739.

Hair, J. F. jr., Anderson, R. E., Tatham, R. L., \& Black, W. C. (1998). Multivari-ate Data Analysis, $5^{\text {th }}$ ed., New Jersey.

Healy, T. J. (1999). Why you should retain your customers. America's Community Banker, 8(9), 2226.

Heskett, J. L., Sasser, W. E. \& Hart, C. W. (1990). Service Breakthroughs - Changing the Rules of the Game, The Free Press, NewYork, NY.

Heskett, J.L., Jones, T.O., Loveman, G.W., Sasser, W.E., Jr., \& Schlesinger, L.A. (1994). Putting the service-profit chain to work. Harvard Business Review, 72(2),164-170.

Hull, L. (2002). Foreign-owned Banks: Implications for New Zealand's Financial Stability. Discussion Paper Series, DP2002/05.

Ioanna, P. D. (2002). The Role of Employee Development in Customer Relations: The Case of UK Retail Banks. Corporate Communication, 7(1), 62-77.

Lovelock, C. H. (1996). Service Marketing, Englewood Cliffs. NJ: Prentice Hall, 122-135.

Likert, R. (1932). A Technique for the Measurement of Attitudes. Archives of Psychology, 140, 1-55.

Kaynak, E., \& Kucukemiroglu, O. (1992). Bank and Product Selection: Hong Kong. The International Journal of Bank Marketing, 10(1), 3-17.

Keller, K. L. (1993). Conceptualizing, measuring and managing customer-based brand equity, Journal of Marketing, 57, 1-22.

Kotler, P. (1997). Marketing Management: Analysis, Planning,Implementation, and Control, 9th ed., Prentice-Hall, Upper Saddle River, NJ.

Kotler, P. (1999). Marketing Management-An Asian Perspective. Singapore: Prentice Hall, Inc., 2530. 
Kuehn, A. (1962). Consumer brand choice as a learning process. Journal of Advertising Research, 2 , $10-17$.

Mazumdar, T. (1993). A value-based orientation to new product planning, Journal of Consumer Marketing, 10(1), 28-41.

Naumann, E. (1995). Creating Customer Value, $1^{\text {st }}$ ed., U.S.A:Thomson Executive Press, Inc.

Nunnally, J.C. (1978). Psychometric theory (pp. 78-95).New York: McGraw-Hill.

Reidenbach, R.E. (1995). Value-Driven Bank: Strategies for Total Market Satisfaction. Irwin Professional, U.K.

Reichheld, F. F \& Kenny, D. (1990). The hidden advantages of customer retention. Journal of Retail Banking, 7(4), 19-23.

Reichheld, F. F. \& Sasser, W.E. Jr (1990). Zero defections: quality comes to services. Harvard Business Review, 68, 105-111.

Reichheld, F.F., Markey, R.G. Jr. \& Hopton, C. (2000). The loyalty effect-the relationship between loyalty and profits. European Business Journal, 12(3), 134-9.

Sheth, J. N. (1991). Consumption Values and Market Choice. South-Western Publishing Co.

Sweeney, J. C. \& Soutar, G. (2001). Consumer perceived value: the development of multiple item scale. Journal of Retailing, 77(2), 203-220.

Woodruff, R. B. (1997). Customer value: the next source of competitive advantage. Journal of the Academy of Marketing Science, 25(2), 139-53.

Wang, Y. G. \& Lo, H. P. (2003). Service quality, customer satisfaction, customer value and behavior intentions: evidence from China's telecommunication industry. The Journal of Policy, Regulation and Strategy for Telecommunications, 4(6), 50-60.

Wang, Y. G., Lo, H. P., Chi, R. Y. \& Yang, Y. H. (2004). An integrated framework for customer value and customer relationship management performance: A customer-based perspective from China. Managing Service Quality, 14 (2/3), 169-182.

Yang, Z., \& Peterson, R. T. (2004). Customer perceived value, satisfaction, and loyalty: The role of switching costs. Psycology and Marketing, 21(10), 799-822.

Zeithaml, V.A., Berry, L. and Parasuraman, A. (1996). The behavioral consequences of service quality. Journal of Marketing, 60 ( 2), 31-46.

Zeithaml, V. A. (1988). Consumer perceptions of price, quality and value: a means-end model and synthesis of evidence. Journal of Marketing, 52, 2-22. 